\title{
The population, utilization and local management of Elaeodendron transvaalense in the Blouberg Municipality, Limpopo Province, South Africa
}

\author{
MARULA TRIUMPH RASETHE ${ }^{1, \boldsymbol{v}}$, SEBUA SILAS SEMENYA ${ }^{2}$ \\ ${ }^{1}$ Limpopo Department of Economic Development, Environment and Tourism. Private Bag X9484, Polokwane, 0700, South Africa. \\ Tel: +27-767843608, `email: truimph.rasethe@gmail.com \\ ${ }^{2}$ Technology Transfer Office, Research Administration and Development Department, University of Limpopo. Private Bag X1106, Sovenga 0727, \\ South Africa
}

Manuscript received: 29 July 2019. Revision accepted: 17 September 2019.

\begin{abstract}
Rasethe MT, Semenya SS. 2019. The population, utilization and local management of Elaeodendron transvaalense in the Blouberg Municipality, Limpopo Province, South Africa. Biodiversitas 20: 2978-2985. Elaeodendron transvaalense is highly harvested by rural communities of the Limpopo Province (South Africa) to meet various livelihoods. However, its information on the population, uses, harvesting practices, threatening factors and local management is still not investigated and documented in many parts of this province. The current study therefore, provides a base-line data of E. transvaalense occurring in two villages of the Blouberg Municipality, Limpopo Province. Data on the population locations, utilization and local management strategies of this species was collected from community members, traditional healers and leaders via semi-structured questionnaires, supplemented by field observations on harvesting practices, threats, area of occupancy, population size, density and demographic structure and population health. Two populations, referred in this study as Sebotlana and Makgabeng covering an area of $25252.17 \mathrm{~m}^{2}$ and $45099.79 \mathrm{~m}^{2}$, respectively, were located in the two villages of the Blouberg Municipality. Both populations were characterized by a mixture of healthy seedlings, sapling, juvenile, middle trees, adult trees, and senescent trees, with Makgabeng population having the highest plant density. Various morphological parts such as bark and roots were mainly used by respondents as common ingredients in traditional medicines, mainly for cough, fever, diarrhoea, symptoms of AIDS and as blood purifier. Evidence of harvesting was only observed on Sebotlana population, which was also highly impacted by rural settlement expansion. Overall, there were no local management strategies meant specifically for the identified E. transvaalense around the Blouberg area.
\end{abstract}

Keywords: Conservation, Elaeodendron transvaalense, management, population, threats, use

\section{INTRODUCTION}

Elaeodendron transvaalense (Burtt Davy) R.H.Archer previously known as Cassine transvaalensis (Burtt Davy) Codd is a South African native plant belonging to Celastraceae family. It is commonly known as Bushveldsaffron (English), Bosveld-saffraan (Afrikaanse), Monamane (Sepedi), Mulumanamana (Venda), uMgugudo (Zulu) and Shimapana (Tsonga), amongst diverse South African ethnic groups.

Geographically, E. transvaalense is widely distributed in various southern African countries including Angola, Botswana, Namibia, Mozambique, South Africa, Zambia, Zimbabwe and Swaziland (Williams et al. 2008). In South Africa specifically, this species is found in the eastern and summer rainfall areas stretching from the KwaZulu-Natal coast northwards through eastern Mpumalanga into Limpopo and North-West Provinces.

Morphologically, E. transvaalense is a small to medium-sized bushy tree that grows from 6 up to $18 \mathrm{~m}$, depending on the environmental conditions and locality. The leaves of this tree are light green to dull grey-green in colour, and have the entire to finely toothed margin, characterized by conspicuous net veins on both sides
(Dlamini 2007). With regards to its flower, it is relatively small and greenish white. The bark of E. transvaalense is pale grey and sometimes finely fissured horizontally (Van Wyk 1996).

Literature study revealed that various morphological parts of E. transvaalense particularly the bark, have been traditionally used for various purposes, especially in traditional medicine as a multiple-therapies in South Africa (Mabogo 1990; Bessong et al. 2005; Tshikalange and Hussein 2010; Tshisikhawe and Van Rooyen 2013) and other African countries such as Kenya (Cunningham 1997); Namibia (Shirungu 2016) where it is widely distributed. Its wood is highly valued in the production of cattle troughs, spoons, ladles, headrests and tobacco pipes in most African countries (Dlamini 2007). Fruits are extensively enjoyed as snack by rural communities (Mabogo 1990).

Due to ongoing high demand coupled with unstainable over-harvesting in the wild and poor wounds recovery following bark stripping for medicinal utilization (Williams et al. 2008; Tshisikhawe and Van Rooyen 2013) E. transvaalense is a priority plant species for conservation in South Africa. Presently, this tree appears as Near Threatened in the South African National Red List Data of plants (Williams et al. 2008). According to this list, a 
species is Near Threatened when available evidence indicates that it nearly meets any of the International Union for Conservation of Nature (IUCN) criteria for Vulnerable, and is, therefore, likely to become at risk of extinction in the near future. Despite this, there is scarcity of studies devoted exclusively on the documentation of the population status of $E$. transvaalense, uses, harvesting practices, and management by rural communities adjacent to its population, even though it has been established that this species is mainly threatened by unstainable overharvesting motivated by its social and economic significance. The current study which was conducted in the Blouberg Municipality will, therefore, contribute to fill this gap in knowledge.

\section{MATERIALS AND METHODS}

\section{Study area}

This study was carried out in two villages namely Sebotlana and Thabananhlana (Makgabeng), located in the Blouberg Municipality of the Capricorn District, Limpopo Province of South Africa (Figure 1).

The vegetation of the studied villages was classified by Mucina and Rutherford (Mucina and Rutherford 2006) as belonging to Soutpansberg Mountain and Roodeberg Bushvelds with Acacia karoo, Dichrostachys cinerea, Dombeya rotundifolia, Mimusops zeyheri, Terminalia sericea, Ziziphus mucronata, and Zanthoxylum capense being amid the important taxa. Climatically, the studied villages fall within the semi-arid summer rainfall area (Mostert et al. 2008), with the mean minimum temperature of $5^{\circ} \mathrm{C}$ rising to a mean maximum temperature of $26^{\circ} \mathrm{C}$ (Scholes 1978). Most people inhabiting the surveyed villages belong to the Hananwa tribe, a distinct minority ethnic group who split from the Hurutshe of Botswana in the 1800's (Boonzaaier and Philip 2007). However, most of these people consider Sepedi as their mother tongue.

\section{Methodology}

Pilot and sampling

A pilot study was first conducted around the Blouberg Municipality to identify local people with the following knowledge of $E$. transvaalense: natural population, distribution, and uses (i.e. medicinal applications and other utilities) (Clement et al. 2015). Local vernacular name (Monamane) of this tree (Figure 2), its colorful image and voucher specimen were systematically used during pilot interviews to determine the local people's (i.e. traditional leader and healers, and ordinary community members) knowledge of the referred tree as specified above. Subsequently, based on the knowledge of local personnel, the researchers were able to locate two E. transvaalense populations in Sebotlana and Thabananhlana villages of the Blouberg Municipality. Hence, these villages were selected as study sites.

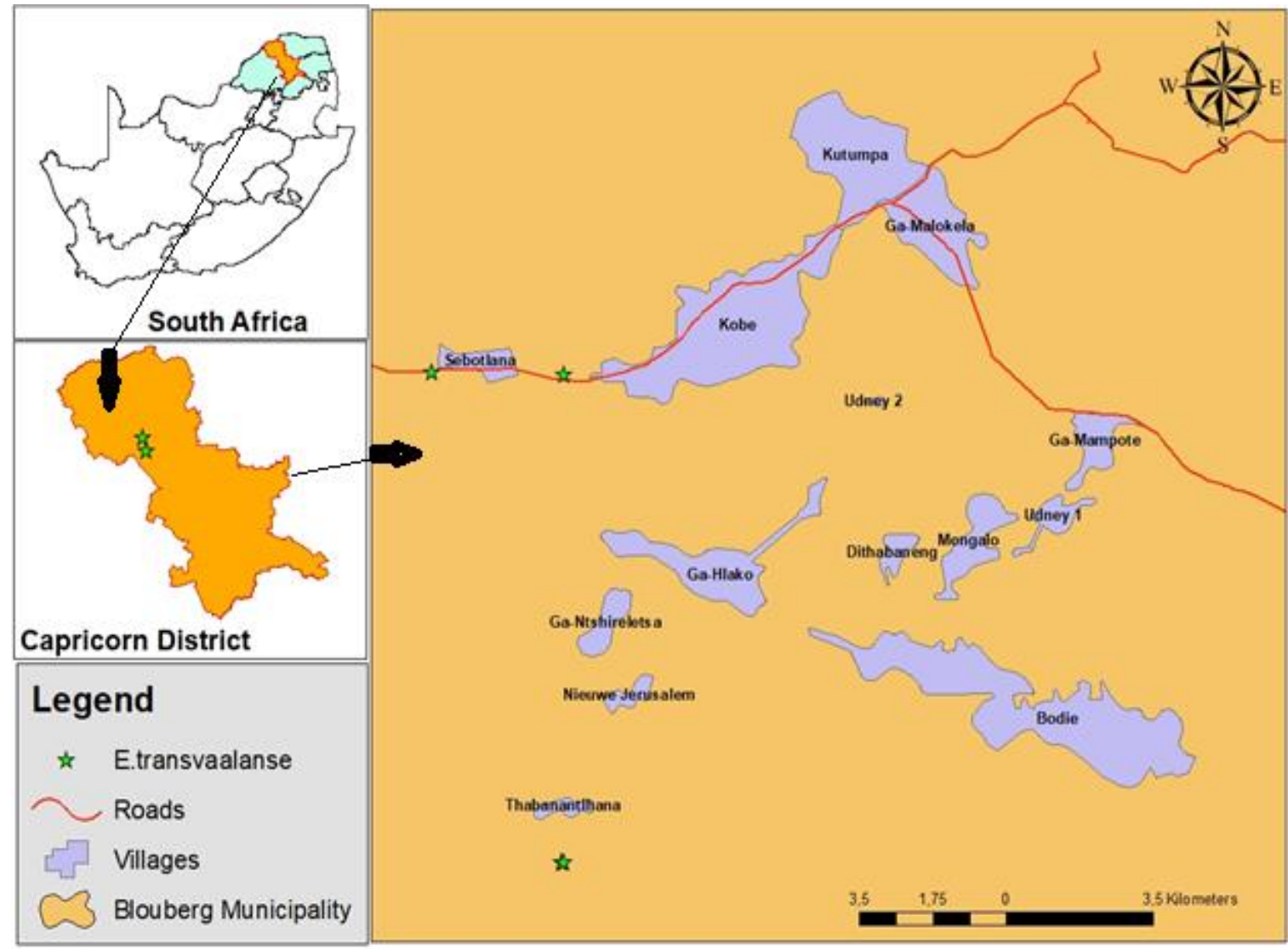

Figure 1. Map of South Africa indicating the studied villages 


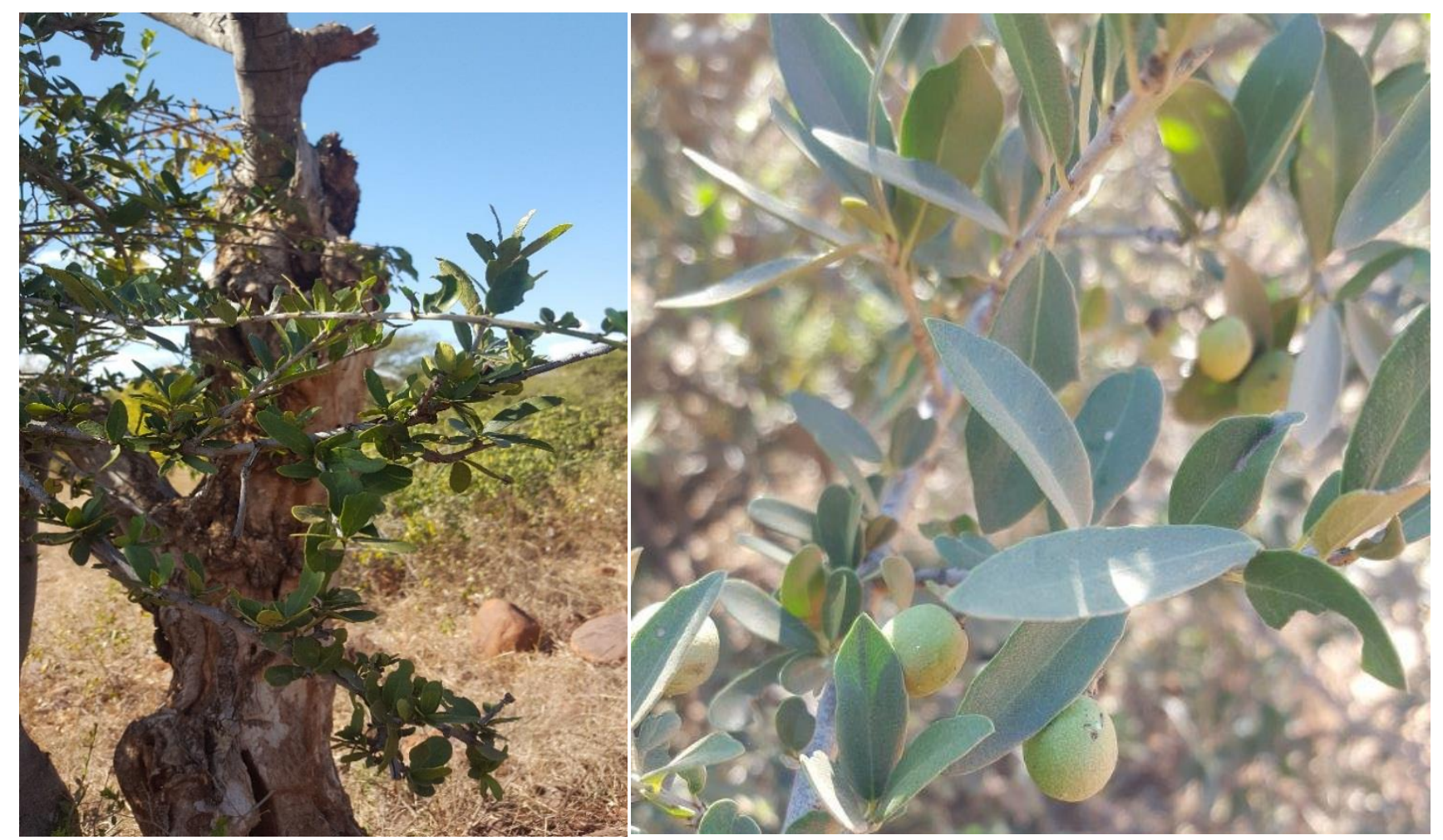

Figure 2. Images of Elaeodendron transvaalense

Fresh voucher specimens were collected from 10 individual species within the two identified populations and deposited at the University of Limpopo Larry Leach Herbarium for further identifications and corroborations of the species. In addition, proper citation of E. transvaalense was confirmed using the Plant List (http://www.theplantlist.org/tpl1.1/search?q=Elaeodendron $+)$. Ethnobotanical and ecological information pertinent to identify the species' populations was collected during second half of study from June to December of 2016.

\section{Population information}

The primary aim of population study was to provide baseline data on the status of the two E. transvaalense populations for future monitoring purposes. Thus, we sought to establish the area of occupancy of population, population structure, and threatening factors.

\section{Area of occupancy}

The size of the area covered by each population was determined using the method of Phama et al. (2014). Following this method, we used a Global Positioning System (GPS) (Garmin $\left.{ }^{\circledR}\right)$ by walking in a circle around the population and recording all the individual plants within the circle. The GPS coordinates of these plants on the boundaries were connected to determine the area of occupancy.

\section{Population size, density and demographic structure}

After determining the area of occupancy by each population, we estimated the population size (number of individuals), its density and demographic structure. Importantly, due to smaller size of both surveyed populations, all individuals were counted during the growing season when plants were easier to identify in these populations in order to establish the population size. The population densities for each population were calculated as total number of individuals (population size) divided by an estimated area of occupancy. To determine the demographic structure of each population we followed method of $\mathrm{Li}$ et al. (2002). For instance, the individual $E$. Transvaalense recorded were categorized into six classes namely: $\mathbf{I}=$ seedling (with height $(\mathrm{H}) 0<\mathrm{H} \leq 100.0 \mathrm{~cm}$ ), $\mathbf{I I}=$ sapling $(\mathrm{H}>100.0 \mathrm{~cm}$, diameter at breast height $(\mathrm{DBH})<$ $3.0 \mathrm{~cm}), \mathbf{I I I}=$ juvenile $(3.0 \mathrm{~cm} \leq \mathrm{DBH}<10.0 \mathrm{~cm}), \mathbf{I V}=$ middle tree $(10.0 \mathrm{~cm} \leq \mathrm{DBH}<15.0 \mathrm{~cm}), \quad \mathbf{V}=$ adult $(15.0 \mathrm{~cm}$ $\leq \mathrm{DBH}<45.0 \mathrm{~cm})$ and $\mathbf{V I}=$ senescent tree $(\mathrm{DBH} \geq 45.0 \mathrm{~cm})$.

\section{Population health}

The assessment of population health was based on individual tree crown characteristics, which serve as good indicators of overall tree health. In this regard, 0 to 5-point scale as previously employed by Sunderland and Tako (1999) was used to evaluate the $E$. transvaalense population health, with 0 (no crown at all) indicating $100 \%$ crown mortality, 1; severe crown damage, 2; moderate crown damage, 3 ; light crown damage, 4 ; traces of crown damage, and 5; a healthy crown. Furthermore, an observation was also made on various potential factors, and/or factors responsible for the depletion of population. Moreover, where possible, plant species that showed signs of being harvested during the survey period were recorded. 


\section{Ethnobotanical information}

A semi-structured questionnaire was used to collect information relating to the utilization/local value of $E$. transvaalense, used parts, harvesting practices, threatening factors, perceived availability status of the species and factors responsible for depletion or change in population compositions, and management practices.

Traditional healers $(n=15)$ and leaders $(n=2)$ as well as lay people (community members, $n=18$ ) who use and harvest $E$. transvaalense from the identified populations were purposely sampled and requested to participate in this study. These respondents were informed about the nature of the study including aim and scope using their mother tongue of Sepedi, and consequently, those who agreed to participate were requested to sign a consent form. Among the respondents, 13 traditional healers, one traditional leader, and seven community members were from Sebotlana village and the rest of them were from Makgabeng village.

\section{RESULTS AND DISCUSSION}

\section{Population information}

The area that was occupied by E. transvaalense varied between the two studied populations namely Sebotlana and Makgabeng. The former population occurred within $45099.79 \mathrm{~m}^{2}$ area and Sebotlana occupied just $25252.17 \mathrm{~m}^{2}$ area. This finding was anticipated due to the fact the larger portion of the latter population was previously cleared for human settlement compared to Makgabeng which is almost without human footprints. However, we observed more suitable habitats for E. transvaalense adjacent to its two studied populations but no plants were found during the survey period. Therefore, it is highly probable that a more and repeated extensive search of species outside the known range of occurrence has the potential to contribute to increasing the area of occupancy of both Sebotlana and Makgabeng populations. The continued harvesting and clearing of first population by human could severely decrease its area of occupancy and ultimately the range of occurrence. As such, urgent initiatives to stop this harmful human activity is needed.

With respect to the population size, Makgabeng was the largest with 152 plant species, and it had the largest area of occupancy, estimated at $45099.79 \mathrm{~m}^{2}$ and the highest density of 0.0034 plants $/ \mathrm{m}^{2}$. Comparably to Makgabeng, Sebotlana population hosted smaller number of species $(n=61)$, with the small density of 0.0024 plants $/ \mathrm{m}^{2}$ in a very small area of occupancy $\left(25252.17 \mathrm{~m}^{2}\right)$. Overall, the population structure of $E$. transvaalense within the two studied populations comprised of mixtures of juveniles, small adults and adults. Generally, adult plants were dominant, followed by senescent tree in both populations. The rest of the demographic structures were either fairly dominant in one or both populations, with middle trees generally being in relatively low abundance in the Sebotlana population (Table 1). The variation in population structure is caused by differences in germination, reproduction and seedling growth, amid other factors. Lesser number of saplings in both studied populations might be due to lack of water which is a factor limiting their early success and establishment (Wilson and Witkowski 1998).

As described earlier, the assessment of population health of E. transvaalense was based on individual tree crown characteristics as previously employed by Sunderland and Tako (1999). However, it should be stated that parts of the crown directly influenced by interactions between crowns (i.e. shading) or competition are excluded during this assessment. The results showed that the majority $(n=69)$ of sampled trees (including those that were impacted by harvesting) in both studied populations falls under the point scale of 5 , thus indicating a healthy crown. Twenty-one percent of the E. transvaalense showed traces of crown damage, only seven percent showed light crown damage and just three percent had moderate crown damage. Furthermore, it showed that these populations can withstand the current levels of harvesting, and that the health of the sampled trees irrespective of their structures had not yet damaged by other factors including drought and fungal diseases. Overall, no noteworthy difference between the two populations with respect to crown health was observed.

\section{Utilization of Elaeodendron transvaalense}

Analysis of our findings regarding the utilization of $E$. transvaalense showed that the species are used for more than one purposes (Table 2). Generally, we categorized these uses in to three major groups namely; (i) medicinal, and (ii) fence materials and (iii) other utilities. The most popular and common therapeutic application of $E$. transvaalense amongst the participants (i.e. traditional leaders, healers, and ordinary community members) was for cough and fever, symptoms of AIDS and blood purifier, respectively. The use of $E$. transvaalense for these conditions concurs with the findings of previous studies. For instance, its therapeutic application against AIDS symptoms was reported by Bessong et al. (2015) amongst the Vhavenda ethnic group residing in the far northern part of the Limpopo Province, South Africa. Tshikalange (2007) who also worked with this ethnic group reported the use of E. transvaalense for cough and fever therapies. The rest of the medicinal use of this species as documented in this survey were restricted to two or one of the above-stated participants.

Other medicinal uses of E. transvaalense against ulcer (Tshisikhawe and Van Rooyen 2012), skin rash (Van Wyk 2000), stomach-ache (Dlamini 2007) and diarrhea (Tshikalange 2007) as depicted in Table 2 is in agreement with the findings of the previous studies. To the best of our knowledge, the other uses of E. transvaalense are recorded in this study for the first time include the therapeutic uses for bleeding gums, blood clot, blood purifier, body pains, clean infected wounds, clean woman after birth, communicate with ancestors, magic (to remove bad luck), migraine headache, treatment of alcohol hangover and tuberculosis. 
Table 1. Population information of Elaeodendron transvaalense distributed in two villages of Blouberg Municipality, Limpopo Province, South Africa

\begin{tabular}{lccccccccc}
\hline \multirow{2}{*}{ Population } & $\begin{array}{c}\text { Area } \\
\left(\mathbf{m}^{2}\right)\end{array}$ & \multirow{2}{*}{ Density } & \multicolumn{6}{c}{ Demographic structure } \\
\cline { 5 - 9 } & & & See & Sap & Juv & Mid & Ad & Sen & Tot no. indiv \\
\hline Sebotlana & 25252.17 & 0.0024 & 14 & 5 & 6 & 1 & 20 & 15 & 61 \\
Makgabeng/Thabananhlana & 45099.79 & 0.0034 & 6 & 9 & 13 & 29 & 58 & 37 & 152 \\
& & & & & & & & &
\end{tabular}

Note: See $=$ Seedling, Sap $=$ Sapling, Juv= Juvenile, Mid=Middle tree, Ad= Adult, Sen= Senescent, Tot no. indiv: Total number of individual species

Table 2. The utilization of Elaeodendron transvaalense in two villages of Blouberg Municipality (Capricorn District), Limpopo Province, South Africa

\begin{tabular}{|c|c|c|c|c|c|c|}
\hline \multirow{2}{*}{ Use category } & \multirow{2}{*}{ Used part } & \multirow{2}{*}{ Methods of use } & \multicolumn{3}{|c|}{ Participants } & \multirow{2}{*}{$\begin{array}{l}\text { Frequency } \\
\text { of use }\end{array}$} \\
\hline & & & $\mathbf{H}$ & TL & $\mathbf{C M}$ & \\
\hline \multicolumn{7}{|l|}{ Medicines } \\
\hline $\begin{array}{l}\text { Cough and } \\
\text { fever }\end{array}$ & Bark & Boiled and extract taken orally & 15 & 2 & 18 & 35 \\
\hline $\begin{array}{l}\text { Enhance } \\
\text { appetite }\end{array}$ & Bark & Freshly harvested bark is chewed & 7 & - & 1 & 8 \\
\hline Stomach-ache & Bark/leaves & Dried and pounded. Taken orally with warm water & 3 & - & - & 3 \\
\hline Diarrhea & Bark & Dried and pounded. Taken orally with warm water & 14 & - & 5 & 19 \\
\hline $\begin{array}{l}\text { Symptoms of } \\
\text { AIDS }\end{array}$ & Bark & Dried and pounded. Taken orally with warm water & 11 & 2 & 18 & 31 \\
\hline Blood purifier & Bark & $\begin{array}{l}\text { Freshly harvested bark is mashed up and macerated in warm } \\
\text { water. Decoction is taken orally }\end{array}$ & 15 & 2 & 13 & 30 \\
\hline Tuberculosis & Root/bark & Dried/freshly harvested bark is boiled and extract taken orally & 3 & - & 1 & 4 \\
\hline Alcer & Fruit & $\begin{array}{l}\text { Taken raw (orally) or mashed and macerated in warm water. } \\
\text { Decoction is taken orally }\end{array}$ & 1 & - & - & 1 \\
\hline $\begin{array}{l}\text { Migraine } \\
\text { headache }\end{array}$ & Root & $\begin{array}{l}\text { Dried and burned in a confined area (such as hut). Smoke is } \\
\text { inhaled }\end{array}$ & 1 & - & - & 1 \\
\hline Skin rash & Bark/leaves & $\begin{array}{l}\text { Freshly harvested bark is mashed up and macerated in warm } \\
\text { water. Decoction is used topically as bath }\end{array}$ & 5 & - & - & 5 \\
\hline $\begin{array}{l}\text { Clean woman } \\
\text { after birth }\end{array}$ & Bark & $\begin{array}{l}\text { Freshly harvested bark is mashed up and macerated in warm } \\
\text { water. Decoction is taken orally }\end{array}$ & 4 & - & - & 4 \\
\hline $\begin{array}{l}\text { Magic (to } \\
\text { remove bad } \\
\text { luck) }\end{array}$ & Bark & $\begin{array}{l}\text { Dried pounded bark is mixed with pigs' fats, and used as body } \\
\text { lotion }\end{array}$ & 7 & - & - & 7 \\
\hline Bleeding gums & Bark & $\begin{array}{l}\text { Freshly harvested bark is mashed up and macerated in warm } \\
\text { water. Decoction is used as oral rinse }\end{array}$ & - & 1 & 4 & 5 \\
\hline Blood clot & Bark & Dried/freshly harvested bark is boiled and extract taken orally & 1 & - & - & 1 \\
\hline Body pains & Bark & $\begin{array}{l}\text { Dried/freshly harvested bark is boiled and extract taken orally. } \\
\text { Same extract can also be used topically as bath }\end{array}$ & 4 & - & 2 & 2 \\
\hline $\begin{array}{l}\text { Treat alcohol } \\
\text { hang over }\end{array}$ & Bark & Dried/freshly harvested bark is boiled and extract taken orally & - & - & 3 & 3 \\
\hline $\begin{array}{l}\text { Clean infected } \\
\text { wounds }\end{array}$ & Bark & $\begin{array}{l}\text { Dried/freshly harvested bark is boiled and warm extract is used } \\
\text { topically to dress wounds }\end{array}$ & 1 & - & - & 1 \\
\hline $\begin{array}{l}\text { Communicate } \\
\text { with ancestors }\end{array}$ & Root & $\begin{array}{l}\text { Dried and burned in a confined area (such as hut) while } \\
\text { speaking with ancestors }\end{array}$ & 1 & - & - & 1 \\
\hline \multicolumn{7}{|l|}{ Fence materials } \\
\hline $\begin{array}{l}\text { Houses and } \\
\text { kraal fences }\end{array}$ & Stem & Dried/freshly harvested bark & - & - & 5 & 5 \\
\hline \multicolumn{7}{|l|}{ Other utilities } \\
\hline Firewood & Stem/branches & Harvested while fresh and dried & - & - & 3 & 3 \\
\hline $\begin{array}{l}\text { Hand hoes used } \\
\text { for ploughing }\end{array}$ & Stem & $\begin{array}{l}\text { Harvested while fresh and outer layer is removed. The stem is } \\
\text { exposed to the sun until it gets dry }\end{array}$ & - & - & 9 & 9 \\
\hline
\end{tabular}

Note: $\mathrm{H}=$ healer, $\mathrm{TL}=$ traditional leader, and $\mathrm{CM}=$ Community member 
Overall, the most frequently treated ailment/condition using E. transvaalense materials in this study were symptoms of AIDS reported by all respondents who use the species. The medicinal knowledge of this tree in the studied area was mainly restricted to the traditional healers as opposed to other participants such as community members and traditional leaders, probably because the interviewed healers practice traditional healing as a profession and therefore bound to know the medicinal applications of most species including E. transvaalense.

The remaining utilization of the investigated plant species encompasses harvesting of stem for the following purposes: construction of both household and kraal fences, firewood, and hand hoes for ploughing which are noted in the present study for the first time. It worth stating that $E$. transvaalense was mentioned exclusively by community members as being used for these purposes (Table 2). Generally, E. transvaalense was less exploited for the above-stated purposes, with household fence and kraal fences, and firewood being the least.

\section{Harvested/used part/s}

Among the harvested morphological parts of $E$. transvaalense, bark was the most commonly preferred $(n=15)$ in this study. Other parts such as root and stem $(n=3$, for each), leaves $(n=2)$, fruits and branches $(n=1$, for each) were less frequently used. With the exclusion of fruits and leaves which were collected during their availability seasons, harvesting of all plant parts by participants was done throughout the year whenever necessary. This finding is not surprising as identifying $E$. transvaalense is very easy due to its conspicuously pale grey and smooth bark. Therefore, once the species is identified, it will be easy to harvest its other morphological parts such roots which are available throughout the year. Apart from the stem which was harvested for fence materials and other utilities, all the afore-mentioned $E$. transvaalense parts were used to prepare traditional medicines, suggesting that this species is mainly locally valued for its utilization in herbal remedies.

\section{Harvesting practices and its impact}

Evidence of E. transvaalense harvesting practices and its impact was only observed within Sebotlana population, while there was no sign of harvesting in Thabananhlana (Makgabeng) population. This indicates that although villagers of Makgabeng are knowledgeable about the value of E. transvaalense (Table 2), they are not active harvesters of the species. Furthermore, such finding might be because the Sebotlana population is located in proximity to the village and some of the species occur along the main road, which makes it easier for the villagers to harvest. Indeed, in Mpumalanga Province of South Africa, it was observed that the intensity of harvesting of specific plant species is influenced by resource abundance and accessibility (Botha et al. 2004a). In the present study, bark from an estimated 31 individual tree species within Sebotlana population was mainly exploited on the eastern and western aspects, attributed to the traditional believes that bark removed from these sides is more effective in healing the ailments. Local traditional healers generally employed this harvesting practice. Plant species harvested for their bark in the eastern and western sides generally comprises of a mixture of big and medium trees, with stem diameter ranging from $5 \mathrm{~cm}$ to $109 \mathrm{~cm}$, depending on the stem size. Therefore, harvesting of $E$. transvaalense bark by traditional healers in the Blouberg Municipality does not target certain tree sizes but is random.

Indications of ringed-bark of numerous $E$. transvaalense individuals (about 8-10 within the population) was also noted in the Sebotlana population during field survey. It should be stated that most of these species were big trees with larger stem sizes $(80-132 \mathrm{~cm})$. However, none of the participants acknowledged ring-barking the species, stating that they are aware of the impact of this harvesting method on the survival of the trees, and they used Warburgia salutaris (G. Bertol.) Chiov (Canellaceae) as an example to demonstrate this. For instance, they stated that most of the $W$. salutaris bark collected via ring-barking has completely dried-out and died. Although we are not certain if it is the case in our study, but selective harvesting of bark from big trees is constantly reported in literature (Cunningham and Mbenkum 1993; Desmet et al. 1996; Botha et al. 2004b; Tshisikhawe et al. 2012) as a practice of commercial harvesters who want to maximize income, and they usually employ harvesting methods such as ring-barking that often cause higher damage to target species. However, field observations in the present study revealed that a greater number $(\mathrm{n}=67)$ of $E$. transvaalense individuals were targeted for their bark via this destructive harvesting method but they seemed to withstand the current levels of harvesting. This is because they generally showed a healthy sign based on the morphological observations (i.e. they were successfully fruiting and developing new branches, and crown were healthy), although no sign of wound recovery from previously exploited species was noted.

About $12 \%$ of E. transvaalense was exploited for their roots. All species irrespective of their sizes (juveniles, small adults and adults) were harvested for this morphological part. However, after the removal of roots, harvesters did not re-fill the pit/hole and this was easily identified by observing the marked effect of a pit. It can be stated that this sort of practice is common amongst traditional healers in the Limpopo Province (Magoro 2008; Semenya 2012) attributed to the traditional belief that filling in of harvest holes will worsen the sickness of patients. Generally, most of the species with the referred effect were juveniles or smaller adults. The practice of not re-filing the soil after removing the roots from the plants clearly show that harvesters are not trained on the sustainable harvesting of medicinal plant species. This is because an open-pit might expose the remaining roots to the sun and eventually dry them, thus affecting species' nutrients and water transportations. Furthermore, it exposes the roots to the fungal attack that might eventually kill the plant. Therefore, the harvest and post-harvest of roots training amongst villagers should be prioritized.

Quantification of E. transvaalense harvested for their leaves was difficult to determine during field survey, primarily because certain animals also browse the leaves. 
However, we asked the participants who use the species' leaves regarding the methods they employ for harvesting, and subsequently, they disclosed that they either hand-pick or break down the branches for collection, irrespective of the tree sizes. Most individual plant species within the population showed a sign of being previously harvested/ browsed and none of them were greatly impacted as new branches were successfully developing and no sign of stress was observed.

Harvesting of stem is frequently noted in literature as the most detrimental to the survival of the targeted species (Hutchings et al. 1996; Ndangalasi et al. 2007; Opperman et al. 2018). With respect to E. transvaalense, only three individual species showed evidence of being exploited for stem, and this obviously resulted in immediate mortality. It worth stating that the basal size of the harvested species clearly showed that harvesters mainly target larger trees for stem harvesting. This practice will alter the population structure of E. transvaalense.

\section{Threatening factors}

Field observations were also made on other factors (apart from the impact of harvesting) affecting the survival of E. transvaalense populations in Makgabeng and Sebotlana. Accordingly, only the latter population was affected. For instance, almost half of the population towards the northern direction was cleared for village development, and hence the village and population shared the demarcation towards the southern aspects. Some of the households were encroaching into the population towards the northern site, triggered by the flatness of the area.

Makgabeng population was almost intact during the field survey with no sign of threat. This finding was expected due to multiple factors including location of population which is far from most communities, distribution of the population in the mountains with taboos and lack of medicinal plants traders in the nearby community.

In addition to the threats observed in the field, local residents adjacent to the two surveyed populations were probed about the threats or possible threats that might affect these populations. Consequently, village expansion, harvesting of bark for herbal trading, self-medication, population clearing for agriculture, timber collection and fire were mentioned by all respondents as the threats that are more likely to affect the Sebotlana population. Fire was the only threat reported by the respondents as the threatening factor of the species diversity and population viability of Makgabeng population. Therefore, the Sebotlana population should be prioritized for conservation due to high threatening factors and possible threats.

\section{Local management of Elaeodendron transvaalense}

The management of natural resources in the studied areas including plants was generally the responsibility of local chief and village indunas (headmen). They were responsible for making plant management rules and ensuring their implementation, as well as increasing awareness of community regarding compliance with the rules. It should be stated that there is no specific management approach meant for E. transvaalense. In this regard, all plant resources around the surveyed villages were managed similarly irrespective of their conservation status. Different plant management strategies employed by chief and indunas of these villages are depicted in Table 3. The tabulated management strategies were not employed or applicable in all two studied villages. However, three plant management strategies namely restriction on the cutting of green trees for firewood, use of sustainable harvesting methods and paid permit for plant harvesting by outsiders were reported by chief and indunas in both villages. It worth stating that this permit did not specify harvest volumes, and might lead to overharvesting of species.

Generally, the local community members including traditional leaders and outsiders are expected to follow such restrictions, and a heavy penalty is imposed on those who do not comply with them. According to the interviewed chiefs and indunas, people who disobey the rules should pay a maximum amount of R 1500.00 fine. Furthermore, they stated that local people are frequently encouraged to report the lawbreakers to the tribal offices.

\section{Conclusion and recommendations}

The current study revealed that people residing in Sebotlana and Makgabeng villages of Blouberg Municipality were knowledgeable about the traditional uses of E. transvaalense, and most importantly its local natural distribution. However, our field observation on the species' local population showed less evidence of harvesting, probably suggesting that the reliant on E. transvaalense by the respondents to meet various needs are declining. Since population identification was based on the surveyed villagers' knowledge and restricted to certain areas of the Blouberg Municipality, it is, therefore, more likely that there are other undiscovered populations which villagers actively harvest from and the populations are not in good health. Generally, the predominant of healthy adult plants (i.e. 58 and 20 individuals in Makgabeng and Sebotlana populations, respectively) is a reflection of a growing population and a significant number of seedlings in both populations. However, the future expansion of the former population will be prevented by the rural settlement. No immediate management intervention is needed for Makgabeng population-based on less threatening factors observed, but the opposite of this can be said for Sebotlana population.

The following two recommendations are key in this study: (i) Both studied populations must be monitored regularly to record any change, identify any threat or possible threat and manage it accordingly. (ii) The local nature conservators must work together with the headmen of Sebotlana population to ensure that no allocation of new stands encroaches the population, and also develop the local management plans/strategies that meant specifically for E. transvaalense. Some of these strategies that should be incorporated include harvesting by registered harvesters under monitoring, specification of the quantity of the material to be harvested, collection of roots from matured adults, and filling in of harvest holes, harvesting during specific season and harvesting of the bark on the eastern or western side of the tree. 
Table 3. Local plant management strategies used in Blouberg Municipality, Limpopo Province, South Africa

\begin{tabular}{|c|c|c|}
\hline \multirow[b]{2}{*}{ Strategy } & \multicolumn{2}{|c|}{ Village } \\
\hline & 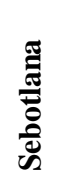 & 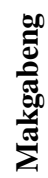 \\
\hline
\end{tabular}

No cutting of green trees for firewood Collection of small quantity of plants Use of sustainable harvesting methods Paid permit for plant harvesting by outsiders Killing of plant is prohibited No harvesting of plants during initiation season

$\begin{array}{ll}+ & + \\ + & - \\ + & + \\ + & + \\ + & - \\ - & +\end{array}$

Note: $\mathrm{X}=$ strategy use, - =strategy not use

\section{ACKNOWLEDGEMENTS}

This project was initiated and wholly supported/funded by the Limpopo Department of Economic Development, Environment and Tourism (Biodiversity section). We owe a depth of gratitude to Nelwamondo P for assistance with fieldwork.

\section{REFERENCES}

Bessong PO, Obi CL, Andreola ML, Rojas LB, Pouysegu L, Igumbor E, Meyer JJ, Quideau S, Litvak S. 2005. Evaluation of selected South African medicinal plants for inhibitory properties against human immunodeficiency virus type 1 reverse transcriptase and integrase. J Ethnopharmacol 99: 83-91.

Boonzaaier CC, Philip L. 2007. Community-based tourism and its potential to improve living conditions among the Hananwa of Blouberg (Limpopo Province), with particular reference to catering services during winter. J Fam Consum Sci 35: 26-38.

Botha J, Witkowski ETF, Shackleton CM. 2004a. Harvesting impacts on commonly used medicinal tree species (Catha edulis and Rapanea melanophloeos) under different land management regimes in the Mpumalanga Lowveld, South Africa. Koedoe 47: 1-18.

Botha J, Witkowski ETF, Shackleton CM. 2004b. The impact of commercial harvesting on Warburgia salutaris (paper-bark tree) in Mpumalanga, South Africa. J Biodivers Conserv 13: 1675-1698.

Clement YN, Baksh-Comeau YS, Seaforth CE. 2015. An ethnobotanical survey of medicinal plants in Trinidad. J Ethnobiol Ethnomed 2015 11: 67. DOI: 10.1186/s13002-015-0052-0.

Cunningham AB, Mbenkum FT. 1993. Sustainability of harvesting Prunus africana bark in Cameroon: A medicinal plant in international trade. People and Plants Working Paper 2. UNESCO, Paris.

Cunningham AB. 1997. An Africa-wide overview of medicinal plant harvesting, conservation and health care. Non-Wood Forest Products, 11: 116-129.

Desmet PG, Shackleton CM, Robinson ER.1996. The population dynamics and life history attributes of a Pterocarpus angolensis DC. population in the Northern Province, South Africa. S Afr J Bot 62: 160-166.
Dlamini MD. 2007. Elaeodendron transvaalense (Burtt Davy) R.H. Archer. South African Biodiversity Institutes, Pretoria.

Hutchings A, Scott AH, Lewis G, Cunningham AB. 1996. Zulu Medicinal Plants: An Inventory. University of Natal Press, Pietermaritzburg.

Li X K, Su Z M, Xiang WS, Ning SJ, Tang RQ, Ou ZY, Li RT. 2002. Study on the structure and spatial pattern of the endangered plant population of Abies yuanbaoshanensis. Acta Ecol Sin 22: 2245-225.

Mabogo DEN. 1990. The Ethnobotany of the VhaVenda. [Thesis]. University of Pretoria, Pretoria.

Magoro MD. 2008. Traditional health practitioners' practices and the sustainability of extinction-prone traditional medicinal plants. [Thesis]. University of South Africa, Pretoria.

Mostert THC, Bredenkamp GJ, Klopper HJ, Verwe C, Mostert RE, Hahn N. 2008. Major vegetation types of the Soutpansberg conservancy and the Blouberg nature reserve, South Africa. Koedoe 50: 32-48.

Mucina L, Rutherford MC. 2006. The Vegetation of South Africa, Lesotho and Swaziland. Strelizia 19, South African National Biodiversity Institute, Pretoria, SA.

Ndangalasi HJ, Bitariho R, Dovie DBK. 2007. Harvesting of non-timber forest products and implications for conservation in two montane forests of East Afr Biol Conserv 134: 242-250.

Opperman EJ, Cherry MI, Makunga NP. 2018. Community harvesting of trees used as dens and for food by the tree hyrax (Dendrohyrax arboreus) in the Pirie forest, South Africa. Koedoe 60: a1481. DOI: 10.4102/koedoe.v60i1.1481.

Phama JO, Panagos MD, Myburgh WJ, Pfab MF. 2014. The population status of the endangered endemic plant Aloe peglerae: Area of occupancy, population structure, and past population trends. S Afr J Bot 93: 247-251.

Scholes RJ. 1978. A Preliminary Ecological Survey of the Blouberg. [Dissertation]. University of Witwatersrand, Johannesburg.

Semenya SS. 2012. Bapedi phytomedicine and their use in the treatment of sexually transmitted diseases in Limpopo Province, South Africa. [Thesis]. University of Limpopo, Mankweng.

Shirungu MMJ.2016. The Use of Medicinal Plants to Treat Mental Illness in Kavango East and West Regions, Namibia. [Dissertation]. University of the Western Cape, Western Cape.

Sunderland TCH, Tako CT. 1999. The exploitation of Prunus africana on the island of Bioko, Equatorial Guinea. A report for People and Plants Initiatives. WWF-Germany, Berlin and the IUCN/SSC Medicinal Plant Specialist Group, Gland.

Tshikalange TE, Hussein A.2010. Cytotoxicity activity of isolated compounds from Elaeodendron transvaalense ethanol extract. J Med Plant Res 4: 1695-1697.

Tshikalange TE. 2007. In Vitro Anti-HIV-1 Properties of Ethnobotanically Selected South African Plants in the Treatment of Sexually Transmitted Disease. [Dissertation]. University Pretoria, Pretoria.

Tshisikhawe MP, Van Rooyen MW, Bhat RB. 2012. An evaluation of the extent and threat of bark harvesting of medicinal plant species in the Venda region, Limpopo Province, South Africa. Intl J Exp Bot 81: 89-100.

Tshisikhawe MP, Van Rooyen MW. 2013. Population biology of Elaeodendron transvaalense Jacq. in the presence of harvesting. Intl $\mathrm{J}$ Exp Bot 82: 303-311.

Van Wyk BE, Gericken N. 2000. People's Plants: A Guide to Useful Plants of Southern Africa. Briza Publication, Pretoria.

Van Wyk P. 1996. Field Guide to the Trees of the Kruger National Park. Struik Publishers, Cape Town, South Africa.

Williams VL, Raimondo D, CrouchNR, Cunningham AB, Scott-Shaw CR, Lötter M, Ngwenya AM. 2008. Elaeodendron transvaalense (Burtt Davy) R.H. Archer. National Assessment: Red List of South African Plants Version 2017.1.

Wilson TB, Witkowski ETF. 1998. Water requirements for germination and early seedling establishment in four African savanna woody plant species. J Arid Environ 38: 541-550. 